\title{
A Comparative Study of the Phenolic and Technological Maturities of Red Grapes Grown in Lebanon
}

\author{
Hiba N. Rajha ${ }^{1,+}$, Nada El Darra ${ }^{2,+}$, Sally El Kantar ${ }^{1}$, Zeina Hobaika ${ }^{1}$, Nicolas Louka ${ }^{1}$ \\ and Richard G. Maroun ${ }^{1, *}$ \\ 1 Unité de Recherche Technologies et Valorisation Agro-alimentaire, Centre d'Analyses et de Recherche, \\ Faculté des Sciences, Université Saint-Joseph, B.P. 11-514 Riad El Solh, Beirut 1107 2050, Lebanon; \\ hiba.rajha@usj.edu.lb (H.N.R.); sally.kantar@net.usj.edu.lb (S.E.K.); zeina.hobaika@usj.edu.lb (Z.H.); \\ nicolas.louka@usj.edu.lb (N.L.) \\ 2 Faculty of Heath Sciences, Beirut Arab University, Tarik El Jedidah-Beirut, P.O. Box 115020 Riad EL Solh, \\ Beirut 1107 2809, Lebanon; n.aldarra@bau.edu.lb \\ * Correspondence: richard.maroun@usj.edu.lb; Tel.: +961-1-421-366; Fax: +961-4-532-657 \\ + These authors contributed equally to this work.
}

Academic Editor: Francesca Giampieri

Received: 20 October 2016; Accepted: 4 January 2017; Published: 26 January 2017

\begin{abstract}
Grape harvest date is determined according to the technological and phenolic maturities. These parameters were calculated for different red grape (Vitis vinifera L.) varieties (Cabernet Sauvignon, Merlot, Syrah, Cabernet Franc) over four years (2008, 2009, 2010, and 2011) (642 samples). Titratable acidity and sugar content of the grapes were used to determine the technological maturity, whereas Glories ( 1 and 2) and ITV (Institut Technique de la Vigne et du Vin) methods were used to monitor their phenolic maturity. The ITV method allows the monitoring of phenolic maturity by the quantification of total polyphenol index and anthocyanins, while the Glories method enables the quantitative evolution of extractable anthocyanins and tannins of the grapes. A correlation was shown between the harvest dates obtained by both ITV and Glories $\left(R^{2}=0.7-0.93\right)$. Phenolic maturity of grapes can, therefore, be optimized by the application of both ITV and Glories. Similarly, a correlation was observed between technological and phenolic harvest dates. The effect of climate on the phenolic content of grapes was also studied. The highest temperatures (up to $25^{\circ} \mathrm{C}$ ) accompanied by the lowest rainfall (null value), induced the maximal concentration of polyphenols in grapes. Thermal and water stresses were also shown to enhance the grapes' polyphenolic production.
\end{abstract}

Keywords: glories; grapes; ITV; phenolic maturity; technological maturity

\section{Introduction}

In the winemaking industry, wine quality is largely influenced by grape harvest time, which is defined by many parameters such as the technological and phenolic maturity of the grapes. Technological maturity is characterized by the sugar content, which determines the potential alcohol content of the future wine, as well as the titratable acidity and $\mathrm{pH}$ of grapes must, which in turn contributes to the color and quality of the wine. In wineries, the sugar content is usually determined by a refractometer to measure the refractive index or by total soluble solids (Degrees Brix) using density studies. Total titratable acidity and $\mathrm{pH}$ are respectively measured by volumetric titration and $\mathrm{pH}$ meter. Phenolic maturity, on the other hand, is evaluated by the ripeness stage of the skin, pulp, and seeds, thus facilitating the choice of the harvest date [1,2]. The concentrations of anthocyanins and tannins, which are the most abundant polyphenols in red grapes, are good indicators of phenolic maturity since they accumulate in the grape skins during the ripening process. Located in cell vacuoles, 
anthocyanins are easily released in the extraction medium when those vesicles are weakened by grape ripening. In wine, instability and reactivity of anthocyanins, together with co-pigmentation reactions, are responsible for the color changing of the wine [3].

Therefore, grape maturity is also defined by the extractability of polyphenols during the winemaking process [4]. Contrarily to the increase in anthocyanin and tannin concentrations in grape skins, seed tannins are less liberated during grape maturity [5]. Wine quality is also related to the climate, rainfall, grape cultivar and soil quality, which affect the phenolic content and grape ripeness [6].

In this study, the phenolic maturity of red grapes grown in the vineyards of Chatteau KSARA S.A.L (Zahlé, Bekaa, Lebanon) was conducted by means of Glories [5,7] and ITV (Institut Technique de la Vigne et du Vin, Narbonne, France) methods [8]. The correlation between both methods was studied in terms of the resulting phenolic harvest dates, based on the extraction kinetics of different components such as anthocyanin content, total polyphenol index, and seed maturity. A comparison between phenolic and technological harvest dates was also undertaken. In addition, the effect of climate (rainfall, temperature) on the grape phenolic content was monitored over a period of four years (2008-2011). This data collection is the first of its kind in the Mediterranean region. It creates a reference about the maturity of the grapes grown in Lebanon over an extended period.

\section{Materials and Methods}

\subsection{Raw Material}

Different grape (Vitis vinifera L.) varieties (Cabernet Sauvignon (CS), Merlot, Syrah, and Cabernet Franc) from different vineyard parcels were studied over four years (2008, 2009, 2010, and 2011). Grape samples were received weekly for several months (from August to October) to monitor phenolic and technological maturity over grape harvest time. Samples were provided by Château KSARA (Zahlé, Bekaa, Lebanon) and identified by a code determined by the vineyard parcel name followed by the grape variety and the planting time of the vine. For example: a sample from domain ITANY, and a Cabernet Sauvignon variety planted in January 1994-1 is coded ITCS41. During the four years, 642 samples were analyzed. In this study, data for Cabernet Sauvignon vines were shown from different parcels and were coded as follows: MVCS51 (domain MANSOURA, Cabernet Sauvignon 1995-1), MVCSK0 (domain MANSOURA, Cabernet Sauvignon 1990), ITCS41 (domain ITANY, Cabernet Sauvignon 1994-1), ITCS42 domain ITANY, Cabernet Sauvignon 1994-2), ITCS51 (domain ITANY, Cabernet Sauvignon 1995-1), ITCS52 (domain ITANY, Cabernet Sauvignon 1995-2), TACS6 (domain TANAYEL, Cabernet Sauvignon B6), KACS31 (domain KANAFAR, Cabernet Sauvignon 1), and KACS32 (domain KANAFAR, Cabernet Sauvignon 2).

\subsection{Technological Maturity}

Technological maturity was determined by the sugar content, titratable acidity and $\mathrm{pH}$. The sugar content was measured by the Brix degree through a digital refractometer (PR-101, Atago, Bellevue, WA, USA) (at $20^{\circ} \mathrm{C}$ ) and converted to sugar content $(\mathrm{g} / \mathrm{L})$ according to the ITV database [9].

Titratable acidity was measured by the acid/base titration using $\mathrm{NaOH} 0.1 \mathrm{~N}$ and bromothymol blue $(4 \mathrm{~g} / \mathrm{L}$ ) as an indicator dye. The $\mathrm{pH}$ of grape juice was measured using a $\mathrm{pH}$ meter (Consor C931, Bioblock Scientific, Paris, France) at $20^{\circ} \mathrm{C}$.

\subsection{Sample Preparation for ITV and Glories Methods}

Several bunches of grapes were received in plastic bags and 200 grape berries were randomly collected from each sample and ground for two minutes. Grape bunch samples were received from the winemaking company which marked four rows per plot for each vine variety. These rows were symmetrically chosen with regards to the size of the plot. Three vines were numbered per row and grape bunches were collected over the two arms of each of the 12 vines. 
Fifty grams of the resulting grape juice were introduced in a $250 \mathrm{~mL}$ Erlenmeyer flask to apply the ITV method. Another $100 \mathrm{~g}$ were placed in two Erlenmeyer flasks ( $50 \mathrm{~g}$ of sample in each) to apply the Glories method.

\subsubsection{ITV (Institut Technique de la Vigne et du Vin) Method}

The ITV reference method was used to measure anthocyanins and total phenolic compound contents of grapes during maturation [8]. Fifteen milliliters of ethanol (95\%) and $85 \mathrm{~mL}$ of $0.1 \%$ $\mathrm{HCl}$ were added to the $50 \mathrm{~g}$ of grape juice. After $1 \mathrm{~h}$ of maceration at $20{ }^{\circ} \mathrm{C}$, the sample was filtered through glass wool. A first sample dilution to 1/100 was done in distilled water and the absorbance was measured using a UV-VIS spectrometer (UV-9200, BioTECH Engineering Management Co. Ltd., Nicosia, Cyprus) at an OD (optical density) of $280 \mathrm{~nm}$ against a blank of distilled water. Total polyphenol index (TPI) was calculated as follows [10]:

$$
\text { Total polyphenol index }=O D_{280} \times 100 \times \frac{(\text { weight of grape juice }+100)}{(\text { weight of grape juice })}
$$

A second sample diluted to $1 / 20$ was done in $1 \% \mathrm{HCl}$ and the $\mathrm{OD}$ was measured at $520 \mathrm{~nm}$ against a blank of distilled water. The concentration of anthocyanins (ANT) and the total anthocyanin potential (TAP) were estimated as follows:

$$
\begin{gathered}
\text { Anthocyanins }\left(\frac{m g}{L}\right)=O D_{520} \times 22.75 \times 20 \\
\text { Total anthocyanins potential }\left(\frac{m g}{k g}\right)=\text { Anthocyanins }\left(\frac{m g}{L}\right) \times 100 \times \frac{(\text { weight of grape juice }+100)}{\text { (weight of grape juice })}
\end{gathered}
$$

\subsubsection{Glories Method}

Fifty milliliters of aqueous solution at $\mathrm{pH} 3.2$ were added to the first $50 \mathrm{~g}$ of sample. The $\mathrm{pH} 3.2$ solution was prepared by adding $5 \mathrm{~g}$ of tartaric acid to water $(1 \mathrm{~L})$ with a $\mathrm{pH}$ adjustment to 3.2 by $\mathrm{NaOH}$. Fifty milliliters of aqueous solution $\mathrm{pH} 1(37 \% \mathrm{HCl}$ in distilled water with $\mathrm{pH}$ adjusted to 1) were added to the second $50 \mathrm{~g}$ of sample. Samples were macerated for $4 \mathrm{~h}$ at $20^{\circ} \mathrm{C}$ then filtered through glass wool. Anthocyanins and total phenolic contents were estimated.

The dosage of anthocyanins is based on the principle of anthocyanin discoloration by $\mathrm{SO}_{2}$ [11]. One milliliter of each filtrate $(\mathrm{pH} 1$ or $\mathrm{pH} 3.2)$ was added to $1 \mathrm{~mL}$ of ethanol $0.1 \% \mathrm{HCl}$ and $20 \mathrm{~mL}$ of concentrated $2 \% \mathrm{HCl} .10 \mathrm{~mL}$ of the mixture and $4 \mathrm{~mL}$ of distilled water were introduced in a first tube while $10 \mathrm{~mL}$ of the mixture and $4 \mathrm{~mL}$ of sodium bisulfite $(15 \%)$ were introduced in the second tube. Bleaching is practically instantaneous. After $20 \mathrm{~min}$, the optical density at $520 \mathrm{~nm}$ was measured against distilled water for both tubes. Anthocyanin concentration (Ant) was given in milligrams (mg) of anthocyanins per liter (L) and calculated as follows:

$$
\operatorname{Ant}\left(\frac{m g}{L}\right)=875 \times\left(O D_{\text {tube } 1 \text { in water }}-O D_{\text {tube } 2 \text { in bisulfite }}\right)
$$

with 875 being the slope of the calibration curve obtained from malvidin-3-glucoside.

Following this calculation, two values are calculated as $A n t_{1}$ and $A n t_{2}$. From these values, several results will be provided:

The potential of easily extractable anthocyanins was calculated as follows:

$$
\text { Antp } H_{3.2}=\text { Dilution factor } \times A_{2}
$$

The total anthocyanin potential was calculated as follows:

$$
\text { Antp } H_{1}=\text { Dilution factor } \times A_{1}
$$


The percentage of extractable anthocyanins (PEA) was calculated as follows:

$$
P A E=\frac{A_{p H} 3.2}{A_{p H 1}} \times 100
$$

Anthocyanin extractability (AE) or cell maturity index was calculated as follows [4]:

$$
A E=\frac{A_{p H 1}-A_{p H} 3.2}{A_{p H 1}} \times 100
$$

To estimate total phenolic richness (TPR) in the extracts macerated at $\mathrm{pH} 3.2$, a dilution to $1 / 100$ was conducted and the optical density was measured at $280 \mathrm{~nm}$ against distilled water. Then overall estimation of total phenolic compounds was calculated:

Total phenolic richness was calculated as follows:

$$
T P R=2 \times O D_{280} \times 100
$$

Seed tannins (ST) were calculated as follows:

$$
S T=R P T-\text { skin polyphenols }=R P T-\frac{A p H 3.2 \times 40}{1000}
$$

The phenolic maturity of the seeds $(S M)$ was calculated as follows:

$$
S M=\frac{S T}{R P T} \times 100
$$

\subsection{Statistical Analysis}

All experiments were repeated at least three times (four measurements were done per sample $(n=4))$. Average and standard deviations of the data were calculated. The average comparison test and the Fisher test (LSD) were applied to compare the results. The confidence interval was set at 5\%. For statistical tests, the Statgraphics Plus 5.1 software (Statpoint Technologies, Inc., Warrenton, VA, USA) was used. Modeling of the experimental curves obtained was carried out using the Table Curve software (2D Windows version 2.03, San Rafael, CA, USA).

\section{Results and Discussion}

\subsection{Harvest Dates of Different Cabernet Sauvignon (CS) Plots}

Figure 1 shows anthocyanin content (mg/L) and total polyphenol index (TPI) (calculated by ITV method) of four different cabernet sauvignon plots (ITCS41, ITCS42, ITCS51, ITCS52) as a function of time, over four years of study $(2008,2009,2010$, and 2011). The anthocyanin content (mg/L) increases to reach a peak (optimal harvest time) and then decreases. This kinetic was observed in many previous studies [12-15]. The decrease of anthocyanins after the peak can be due to the combination of anthocyanins and tannins [16]. For the same year, the peak of anthocyanins is almost reached at the same date for all the plots. For example, the optimal harvest time of ITCS41, ITCS42, ITCS51 and ITCS52 was 29 September 2011. Moreover, all the concentrations of anthocyanins (at harvest time) in 2008 and 2010 are higher than those obtained in 2009 and 2011. The values of TPI increase in the beginning of grape maturation to reach a peak, then gradually decrease. This was observed for the four plots of CS and over the four years. Similarly to anthocyanin content, the levels of TPI in 2008 and 2010 are higher than those obtained in 2009 and 2011. Moreover, the TPI peaks were reached at the same time than those of anthocyanin content. 

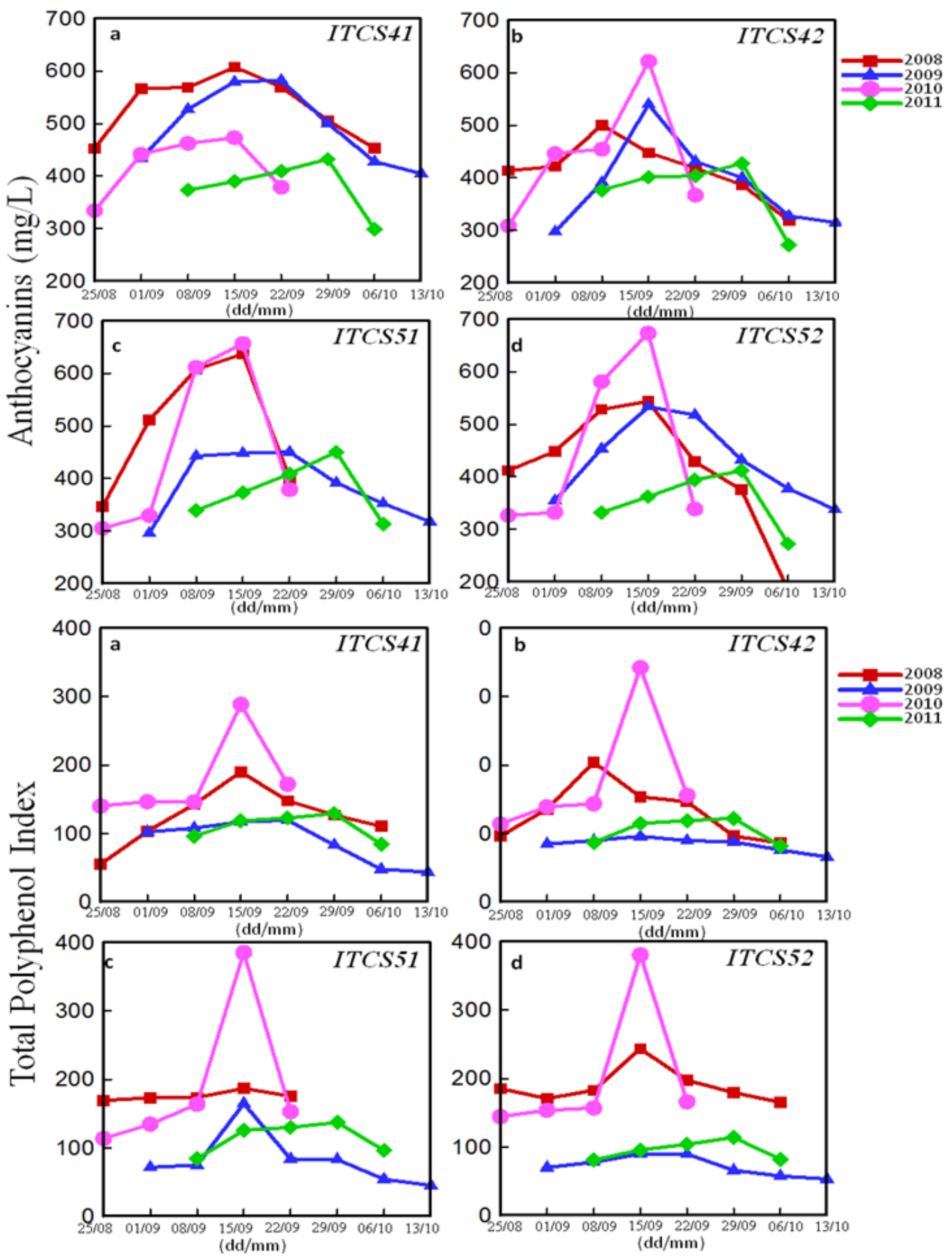

Figure 1. Anthocyanin content (mg/L) and total polyphenol index (IPT) (calculated by Institut Technique de la Vigne et du Vin (ITV) method) of four plots ITCS41 (a); ITCS42 (b); ITCS51 (c); and ITCS52 (d) of Cabernet Sauvignon grapes as a function of time (day (dd)/month (mm)) over four years $(2008,2009,2010$, and 2011).

Figure 2 shows, respectively, the total anthocyanin potential (AntpH1) and the percentage of extractable anthocyanins (PEA) (calculated by the Glories method) of four different cabernet sauvignon plots (ITCS41, ITCS42, ITCS51, ITCS52) as a function of time. The evolution of the Glories parameters (AntpH1 and PEA) is similar to those of ITV (anthocyanins and TPI). AntpH1 and PEA increase to a maximum value then decrease. The highest values were obtained in 2008 and 2010. 

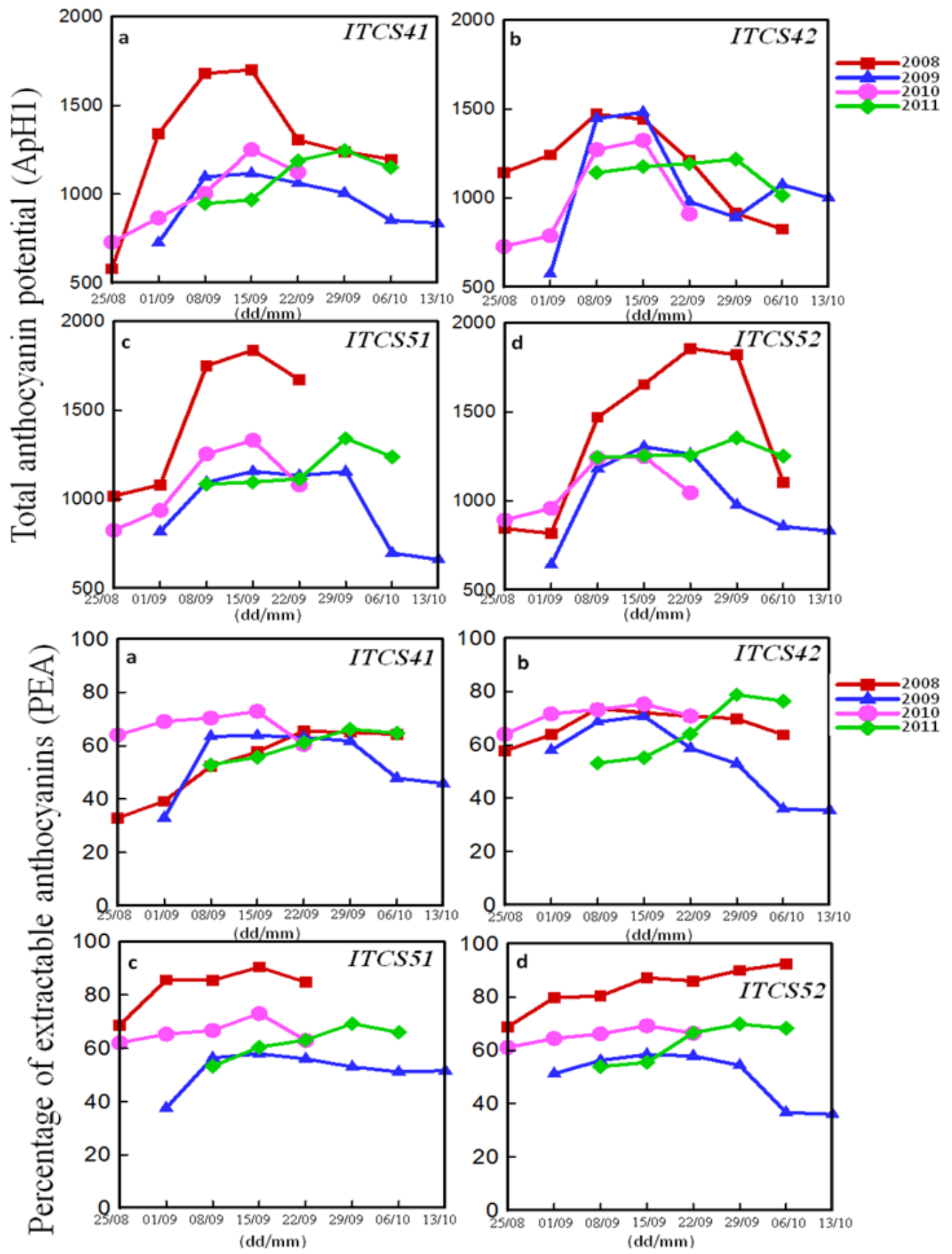

Figure 2. Total anthocyanin potential (AntpH1) and percentage of extractable anthocyanin (PEA) (calculated by Glories method) of four plots ITCS41 (a); ITCS42 (b); ITCS51 (c); and ITCS52 (d) of Cabernet Sauvignon grapes as a function of time (day (dd)/month (mm)) over four years $(2008,2009$, 2010, and 2011).

Figure 3 shows the evolution of seed maturity (SM) (calculated by the Glories method) as a function of time for different plots of CS. SM gradually decreases to reach a plateau. SM determines the role of seeds in the tannin content of the wine. The low values of SM are an indicator of high quality due to the higher proportion of skin tannins permitting the amplification of the extraction during grape maceration. Skin tannins are involved in the tannins-anthocyanins complex formation responsible for the wine color. A high amount of skin tannin, therefore, leads to a stable color [17]. 

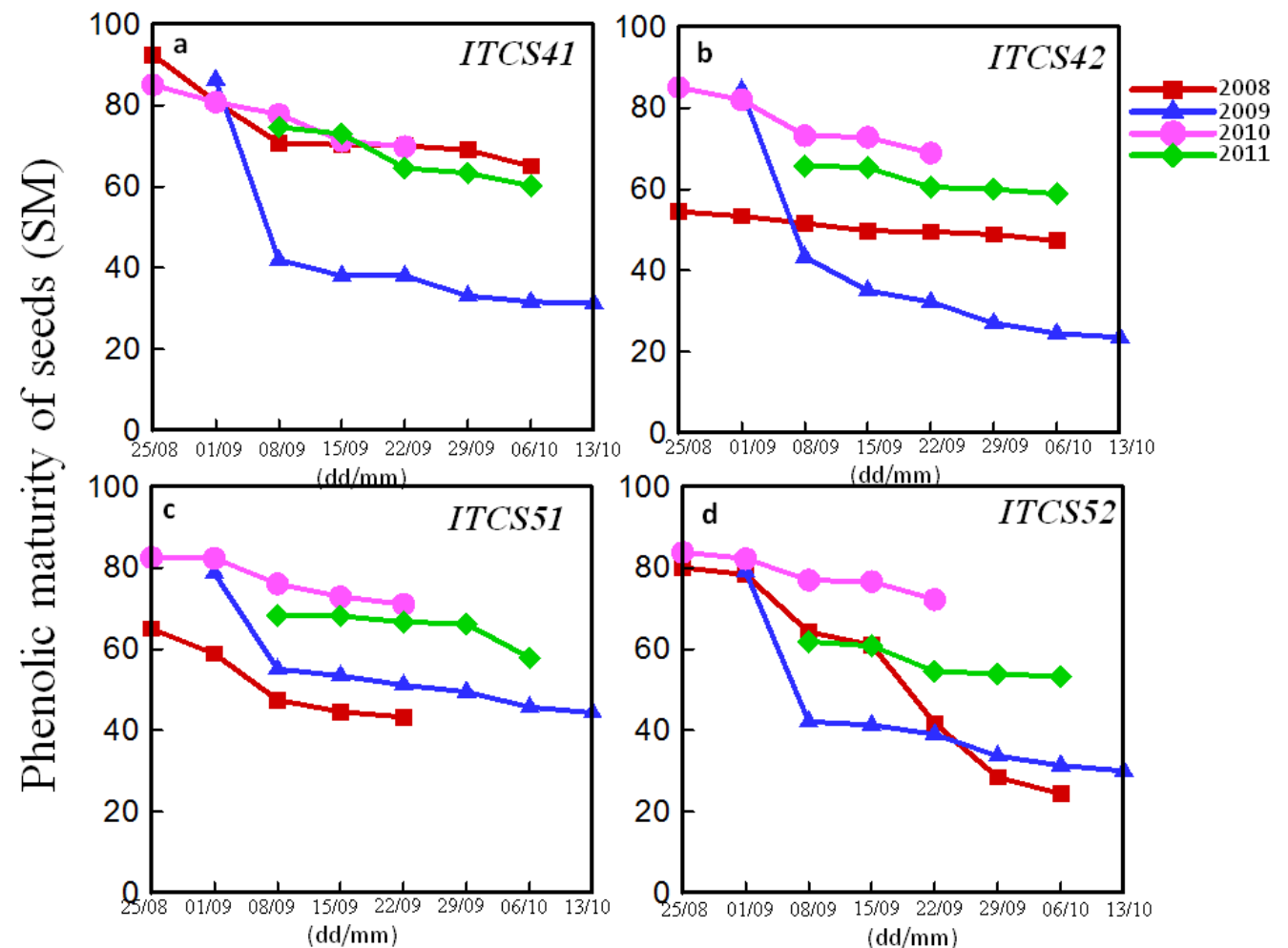

Figure 3. Seeds phenolic maturity of four plots ITCS41 (a); ITCS42 (b); ITCS51 (c); and ITCS52 (d) of Cabernet Sauvignon grapes as a function of time (day (dd)/month (mm)) over four years $(2008,2009$, 2010, and 2011).

\subsection{Comparison between ITV and Glories Methods}

\subsubsection{Phenolic Peaks}

Table 1 shows the dates of the total polyphenol index (TPI) peaks obtained by the ITV method and the total phenolic richness (TPR) peaks obtained by the Glories method for all the plots of Cabernet Sauvignon (in 2008). The dates of the peaks for TPI and TPR are almost the same for all of the studied samples, even from different plots and domains (Supplementary Materials Table S1).

Table 1. Dates of peaks of the total polyphenol index and phenolic richness for each plot of Cabernet Sauvignon respectively detected by the ITV and Glories methods (1 and 2) for 2008 and 2009 harvests.

\begin{tabular}{ccccccc}
\hline Domain & \multirow{2}{*}{ Plot } & Codex & \multicolumn{2}{c}{$\begin{array}{c}\text { Peaks of Total Polyphenol } \\
\text { Index (mg/L) (ITV Method) }\end{array}$} & \multicolumn{2}{c}{$\begin{array}{c}\text { Peaks of Phenolic Richness } \\
\text { (RPT) (Glories Method) }\end{array}$} \\
\cline { 4 - 8 } & & & Harvest 2008 & Harvest 2009 & Harvest 2008 & Harvest 2009 \\
Itany & Cabernet 1994-1 & ITCS41 & 15-September & 14-September & 15-September & 14-September \\
Itany & Cabernet 1994-2 & ITCS42 & 8-September & 14-September & 8-September & 14-September \\
Itany & Cabernet 1995-1 & ITCS51 & 15-September & 14-September & 15-September & 14-September \\
Itany & Cabernet 1995-2 & ITCS52 & 15-September & 14-September & 22-September & 14-September \\
\hline
\end{tabular}

The same results were obtained for the years 2010 and 2011 and with other parameters of ITV and Glories, such as anthocyanin and AntpH1 peaks (Supplementary Materials Table S2). Given that the grape harvest dates were the same, a strong correlation therefore exists between the Glories and ITV methods. Both methods were shown to be adequate to measure grape phenolic maturity predicting some of the wine's characteristics. High correlation coefficients were shown between anthocyanin content and TPI of harvested grapes with their corresponding produced wine [18]. 


\subsubsection{Correlation Matrix of ITV and Glories Parameters}

The correlation matrix between the ITV and Glories parameters for Cabernet Sauvignon grapes over the four years $(2008,2009$, 2010, and 2011) was also conducted (Supplementary Materials Table S3). A strong correlation was shown between the parameters (anthocyanins (ANT), total anthocyanin potential (TAP) and total polyphenol index (TPI)) obtained by the ITV method. $\left(\mathrm{R}^{2}=0.7-0.93\right)$. For the Glories method, the correlation is strong between the total anthocyanins potential (AntpH1) and the potential of extractable anthocyanins (AntpH3.2). The ITV method allows the monitoring of phenolic maturity by the quantification of total phenolic compounds and anthocyanins. However, the quantitative evolution of anthocyanins in grapes is simultaneously done with that of tannins. The latter are quantified by the Glories method. Phenolic maturity of grapes is, therefore, optimized by the application of both ITV and Glories. The correlation between ITV and Glories was validated for Vitis vinifera L. grapes belonging to different varieties: Cabernet Sauvignon, Merlot, Syrah and Cabernet Franc. The interdependence between the technological and phenolic maturities was observed for the determination of harvest dates for the grapes of different varieties. However, the concentration in phenolic content was different between the different varieties.

\subsection{Comparison between Technological and Phenolic Harvest Dates}

Technological maturity can be determined by different indices such as titratable acidity and sugar content, whereas phenolic maturity takes into account anthocyanins, tannins and total phenolic concentration. The latter defines grape maturity and the phenolic compounds potential required in the future wine.

Table 2 shows technological harvest dates and phenolic peak for different plots of Cabernet Sauvignon in 2008. For all of the studied grape samples over 2008, 2009 and 2011 (data not shown), KACS31 and KACS32 plots for the KANAFAR domain; ITCS41 ITCS42, ITCS51 and ITCS52 plots for the ITANY domain, and MVCS51 and MVCSK0 plots for the MANSOURA domain present early phenolic peak dates compared to technological harvest dates. This implies that these plots have reached a full phenolic maturity before being harvested. Indeed, the technological harvest date is one week late compared to the phenolic peak. Moreover, Cabernet Sauvignon is a grape variety that must be harvested slightly overripe (about a week after the peak of anthocyanins) [15,19]. The plots of CS grapes were therefore harvested at an optimum date in 2008, 2009, and 2011 since both technological and phenolic maturities were reached. For the harvest in 2010 (Supplementary Materials Table S4) and for the majority of plots (MVCSK0, ITCS51, ITCS52, TACS6, KACS31, and KACS32), the phenolic harvest peak was slightly delayed compared to the technological harvest date. Over four years, the majority of Cabernet Sauvignon grapes presented a good phenolic ripeness when they were harvested.

Table 2. Technological harvest date and phenolic peak for each plot of Cabernet Sauvignon for the 2008 vintage.

\begin{tabular}{ccccc}
\hline Domain & Plot & Codex & \multicolumn{2}{c}{ Date of Harvest 2008 } \\
\hline & & & Technological & Phenolic \\
Mansoura & Cabernet Y. HA. 1995-1 & MVCS51 & 22 to 25-September & 15-September \\
Mansoura & Cabernet K. CH. 1990 & MVCSK0 & 15 to 17-September & 8-September \\
Itany & Cabernet 1994-1 & ITCS41 & 18 to 20-September & 15-September \\
Itany & Cabernet 1994-2 & ITCS42 & 18-September & 8-September \\
Itany & Cabernet 1995-1 & ITCS51 & 20 to 24-September & 15-September \\
Itany & Cabernet 1995-2 & ITCS52 & 19 to 23-September & 15-September \\
Taanayel & Cabernet B6 & TACS6 & 25 to 10-October & 29-September \\
Kanafar & Cabernet 1 & KACS31 & 18 to 19-September & 15-September \\
Kanafar & Cabernet 2 & KACS32 & 18-September & 15-September \\
\hline
\end{tabular}




\subsection{Evolution of Climate for 2008, 2009, 2010 and 2011 Harvests}

The climate is an important factor that determines the quality of the wine [10] since the synthesis of phenolic compounds depends on it. More specifically, the quality of the wine is affected by the average annual precipitation and temperature [15]. Figure 4 shows the average annual amount of rainfall $(\mathrm{mm})$ and temperature $\left({ }^{\circ} \mathrm{C}\right)$ over the four studied years.
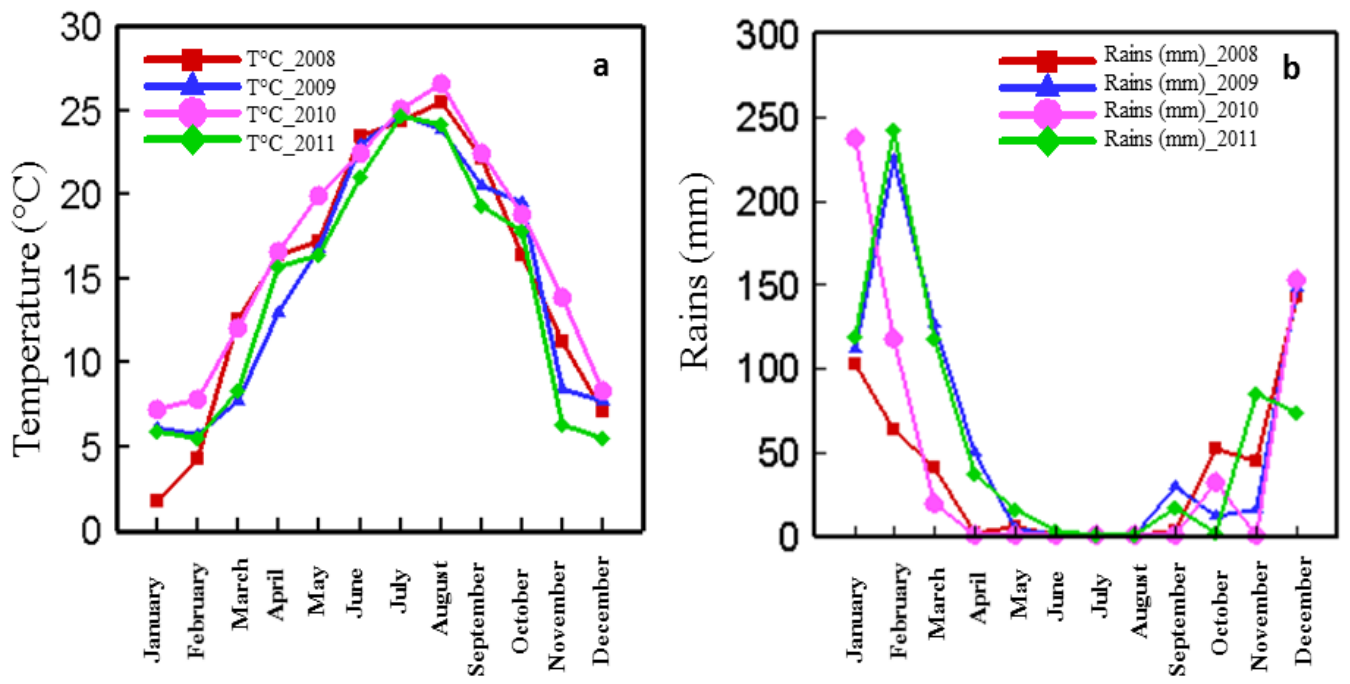

Figure 4. Temperature (a) and rainfall (b) as a function of time over four years (2008, 2009, 2010, and 2011).

The evolution of temperature as a function of months is similar in 2008, 2009, 2010, and 2011. It gradually increases to reach a peak in August, then decreases. For the four Cabernet Sauvignon samples, phenolic and anthocyanin peaks were reached in September (Figure 1). Higher temperatures were observed during September 2008 and $2010\left(\mathrm{~T}=22.16^{\circ} \mathrm{C}\right.$ and $22.42^{\circ} \mathrm{C}$, respectively) compared to 2009 and 2011 ( $\mathrm{T}=20.55^{\circ} \mathrm{C}$ and $19.37^{\circ} \mathrm{C}$, respectively). Similarly, the harvest dates of phenolic peaks for Cabernet Franc, Merlot, Syrah, and Petit Verdot had higher temperatures in 2008 and 2010, compared to 2009 and 2011. The highest temperatures observed in 2008 and 2010 were correlated to a higher phenolic and anthocyanin potentials of grapes. A warmer climate was shown to damage grape skins, thus improving anthocyanin and phenolic extractability [20]. Moreover, the accumulation of anthocyanins in grape skins was shown to be favored by high temperatures, thus affecting grape color [21]. The resulting wine is therefore rich in aromas, anthocyanins and phenolic compounds [10,22].

The evolution of the annual average precipitation as a function of months is similar in 2008, 2009, 2010, and 2011. It gradually decreases to reach null values in June, July and August, and then increases (Figure 4). During September, corresponding to the CS phenolic peaks, rainfall values were $0 \mathrm{~mm}$, $3 \mathrm{~mm}, 16.5 \mathrm{~mm}$, and $29 \mathrm{~mm}$ in 2010, 2008, 2011, and 2009 respectively. A higher phenolic potential was observed in the 2008 and 2010 harvest also for Cabernet Franc, Merlot, Syrah, and Petit Verdot varieties (data not shown), which were drier years than 2009 and 2011. Water stress was shown to increase the synthesis of phenolic compounds [23,24]. A restriction of water supply to the vines increases the quality potential of the harvests, especially for the production of red wines [23,24]. Moreover, anthocyanin peak dates in 2008 and 2010 were precocious for all grape varieties compared to 2009 and 2011. It has been shown that drought accelerates grape maturity [25].

\section{Conclusions}

Technological maturity of 642 samples was determined by the measurement of the titratable acidity and sugar content of the grapes. Glories and ITV methods were used to define their phenolic maturity. The correlation between ITV and Glories suggested that both methods are complementary to identify optimal harvest dates. Similarly, interdependence was observed between technological 
and phenolic maturity for the determination of harvest dates. The hottest and driest years enhanced phenolic compound quantities in grapes. All of the obtained results were validated for Vitis vinifera $\mathrm{L}$. grapes belonging to different varieties: Cabernet Sauvignon, Merlot, Syrah, and Cabernet Franc.

Supplementary Materials: The following are available online at www.mdpi.com/2076-3921/6/1/8/s1, Table S1. Page 7_line 16: Dates of peaks of total polyphenol index (TPI) and phenolic richness (RPT) for each plot of Cabernet Sauvignon respectively detected by the ITV and Glories methods (1 and 2) for 2008, 2009, 2010 and 2011 harvests. Table S2. Dates of peaks of anthocyanin (ANT) and the potential of easily extractable anthocyanins (AntpH3.2) for each plot of Cabernet Sauvignon respectively detected by the ITV and Glories methods ( 1 and 2) for 2008, 2009, 2010 and 2011 harvests. Table S3. Correlation matrix between ITV and Glories parameters for Cabernet Sauvignon grapes over four years $(2008,2009,2010$ and 2011). Table S4. Technological harvest date and phenolic peak for each plot of Cabernet Sauvignon for the 2008, 2009, 2010 and 2011 vintage.

Acknowledgments: The authors would like to acknowledge the Research Council of Saint-Joseph University of Beirut for financial support through Project FS54 and château KSARA for providing grapes.

Conflicts of Interest: The authors declare no conflict of interest. We hereby certify that the work we are submitting is original and that all authors have contributed significantly and are in agreement with the manuscript.

Author Contributions: Richard G. Maroun conceived and designed the experiments. Hiba N. Rajha, Nada El Darra and Sally El Kantar performed the experiments in the laboratory during the four years. Richard G. Maroun, Nicolas Louka, Zeina Hobaika, Hiba N. Rajha, Nada El Darra and Sally El Kantar analyzed the data and wrote the paper.

\section{References}

1. Ferrer-Gallego, R.; Hernández-Hierro, J.M.; Rivas-Gonzalo, J.C.; Escribano-Bailón, M.T. Influence of climatic conditions on the phenolic composition of Vitis vinifera L. cv. Graciano. Anal. Chim. Acta 2012, 732, 73-77. [CrossRef] [PubMed]

2. Meléndez, E.; Ortiz, M.C.; Sarabia, L.A.; Íñiguez, M.; Puras, P. Modelling phenolic and technological maturities of grapes by means of the multivariate relation between organoleptic and physicochemical properties. Anal. Chim. Acta 2013, 761, 53-61. [CrossRef] [PubMed]

3. Boselli, E.; Boulton, R.B.; Thorngate, J.H.; Frega, N.G. Chemical and sensory characterization of DOC red wines from Marche (Italy) related to vintage and grape cultivars. J. Agric. Food Chem. 2004, 52, 3843-3854. [CrossRef] [PubMed]

4. Ribéreau-Gayon, P.; Dubourdieu, D.; Donèche, B.; Lonvaud, A. (Eds.) Handbook of Enology. The Chemistry of Wine and Stabilisation and Treatments; John Wiley \& Sons: Chichester, UK, 2000; Volume 2, pp. 141-203.

5. De Gaulejac, N.S.-C.; Vivas, N.; Glories, Y. Maturation phénolique des raisins rouges. Relation avec la qualité des vins. Comparaison des cépages Merlot et Tempranillo. Le Progrès Agricole et Viticole 1998, 115, 306-318.

6. Van Leeuwen, C.; Friant, P.; Chone, X.; Tregoat, O.; Koundouras, S.; Dubourdieu, D. Influence of climate, soil, and cultivar on terroir. Am. J. Enol. Vitic. 2004, 55, 207-217.

7. Joutei, K.A.; Bouya, D.; Saucier, C.; Glories, Y. Influence de l'éthylène sur les maturités phénolique et cellulaire des raisins au cours de la vinification. Cah. Agric. 2006, 15, 371-374.

8. Lamadon, F. Protocole pour l'évaluation de la richesse polyphénolique des raisins. Revue des OEnologues. 1995, 76, 37-38.

9. Blouin, J.; Guimberteau, G. Maturation et Maturité des Raisins. Available online: http://www.advid.pt/ imagens/comunicacoes/14104343276058.pdf (accessed on 6 January 2016).

10. Laure, C.; Cottereau, P.; Renord, R. Estimation de la Maturité Phénolique des Raisins Rouges par la Méthode ITV Standard. Available online: http://www.oenologuesdefrance.fr/gestion/fichiers_publications/Cayla_ Cott.pdf (accessed on 6 January 2017).

11. Ribéreau-Gayon, P.; Stonestree, E. Le dosage des anthocyanes dans le vin rouge. Bull. Soc. Chim. Fr. 1965, 9 , 2649-2652. [PubMed]

12. Canals, R.; Llaudy, M.C.; Valls, J.; Canals, J.M.; Zamora, F. Influence of ethanol concentration on the extraction of color and phenolic compounds from the skin and seeds of Tempranillo grapes at different stages of ripening. J. Agric. Food Chem. 2005, 53, 4019-4025. [CrossRef] [PubMed]

13. Bautista-Ortín, A.B.; Martínez-Cutillas, A.; Ros-García, J.M.; López-Roca, J.M.; Gómez-Plaza, E. Improving colour extraction and stability in red wines: The use of maceration enzymes and enological tannins. Int. J. Food Sci. Tech. 2005, 40, 867-878. [CrossRef] 
14. De La Hera Orts, M.L.; Martínez-Cutillas, A.; Roca, J.L.; Pérez-Prieto, L.J.; Gómez-Plaza, E. Effect d'une irrigation déficitaire sur la teneur en anthocyanes des raisins et des vins issus du cépage Monastrell. J. Int. Sci. Vigne Vin 2005, 39, 47-55.

15. Anneraud, C.; Vinsonneau, E. Maturité Technologique et Maturité Phénolique des Raisins: Des Références Analytiques Utiles, des Méthodes Simples et des Matériels Pratiques et Prometteurs. Available online: http://www.matevi-france.com/uploads/tx_matevibase/Maturite_technologique_ Maturite_phenolique_des_raisins_References_analytiques_Methodes_simples_Materiels.pdf (accessed on 20 October 2016).

16. Jackson, R.S. Wine Science: Principles and Applications, 4th ed.; Elsevier: London, UK, 2014.

17. El Darra, N. Les Composés Phénoliques des Raisins: Étude Du Potentiel Qualitatif et des Procédés émergeants d'extraction. Ph.D. Thesis, 21 January 2012.

18. Kontoudakis, N.; Esteruelas, M.; Fort, F.; Canals, J.M.; Zamora, F. Comparison of methods for estimating phenolic maturity in grapes: Correlation between predicted and obtained parameters. Anal. Chim. Acta 2010, 660, 127-133. [CrossRef] [PubMed]

19. Dupuch, V. Maturité phénolique et dates de récoltes: les apports de la méthode «CASV». Journ. Tech. Cinquantenaire ITV Fr. 1998, 8, 3-13.

20. Lorrain, B.; Chira, K.; Teissedre, P.-L. Phenolic composition of Merlot and Cabernet-Sauvignon grapes from Bordeaux vineyard for the 2009-vintage: Comparison to 2006, 2007 and 2008 vintages. Food Chem. 2011, 126, 1991-1999. [CrossRef] [PubMed]

21. Carbonneau, A.; Riou, C.; Guyon, D.; Riom, J.; Schneider, C. Agrométéorologie de la vigne en France; Office des Publications Officielles des Communautés Européennes: Luxembourg, Luxembourg, 1992; p. 169.

22. Coombe, B.G. Distribution of solutes within the developing grape berry in relation to its morphology. Am. J. Enol. Vitic. 1987, 38, 120-127.

23. Van Leeuwen, C.; Seguin, G. Incidences de l'alimentation en eau de la vigne, appréciée par l'état hydrique du feuillage, sur le développement de l'appareil végétatif et la maturation du raisin (Vitis vinifera variété Cabernet franc, Saint-Emilion, 1990). J. Int. Sci. Vigne Vin 1994, 28, 81-110.

24. Tregoat, O.; Van Leeuwen, C.; Choné, X.; Gaudillère, J.P. Etude du régime hydrique et de la nutrition azotée de la vigne par des indicateurs physiologiques. Influence sur le comportement de la vigne et la maturation du raisin. J. Int. Sci. Vigne Vin 2002, 36, 133-142.

25. Morlat, R. Le Terroir Viticole: Contribution à L'étude de sa Caractérisation et de Son Influence sur les vins. Application aux Vignobles Rouges de la Moyenne Vallée de la Loire. Revue française d'oenologie. 1992, 32, S6-S13.

(C) 2017 by the authors; licensee MDPI, Basel, Switzerland. This article is an open access article distributed under the terms and conditions of the Creative Commons Attribution (CC BY) license (http:/ / creativecommons.org/licenses/by/4.0/). 